\author{
ANNA SOBIECKA \\ (iD https://orcid.org/0000-0001-5155-0393 \\ Akademia Pomorska w Słupsku \\ Stupsk
}

\title{
Koncepcja dramatu wewnętrznego Szaloma Asza
}

\begin{abstract}
Sholem Asch's interior drama concept
Abstract: The aim of the paper is to present the dramatic works of Sholem Asch with reference to the basic characteristics of the Young Poland period "interior drama", further specified by Jerzy Waligóra as a manifestation of the processes of drama subjectivisation in the late 19th/early 20th century. Departing from the traditional perception of Asch's dramatic works in the context of the literary heritage of the Polish-Jewish borderlands or the modernist symbolic drama makes it possible to interpret his works as identity drama, based on the need to choose between what was and what will be, between the past with its tradition on the one hand, and the present with the related modernity on the other hand.

Key words: Sholem Asch, identity drama, modernist symbolic drama, Young Poland, Polish-Jewish heritage
\end{abstract}

Umiejscowienie dramaturgii Szaloma Asza w kontekście dziedzictwa literackiego pogranicza polsko-żydowskiego bądź też modernistycznego dramatu symbolicznego wydaje się zabiegiem jak najbardziej słusznym. Potwierdzają to wcześniejsze ustalenia poczynione między innymi przez Annę Kuligowską-Korzeniewską (Kuligowska-Korzeniewska 2011), Agatę Dąbrowska (Dąbrowska 2015), Magdalenę Sitarz (Sitarz 2013) czy Daniela Kalinowskiego (Kalinowski 2013). Możliwe wydaje się także przesunięcie akcentów analityczno-interpretacyjnych w kierunku dramatu, który określić można mianem dramatu etnograficznego czy nawet autoetnograficznego, na wzór „powieści etnograficznej” w ujęciu zaproponowanym przez Eugenię Prokop-Janiec (Prokop-Janiec 2010, 11-31). Jej koncepcja powieści etnograficznej ${ }^{1}$ - i szerzej literatury etnograficznej - jako ,gatunku zmąconego”,

${ }^{1}$ Badania nad powieścią etnograficzną Prokop-Janiec sytuuje w szerszym zjawisku określonym mianem etnopoetyki, przynależącym do kulturowej teorii literatury (zob. Prokop-Janiec 2012, 185-227). 
dążącego do odtwarzania określonej rzeczywistości kulturowej opartej na pakcie zawieranym między czytelnikiem a narratorem-etnografem („uczestniczącym obserwatorem"), usiłującym zaprezentować pewien wycinek osobistego doświadczenia kulturowego (zob. Prokop-Janiec 2010, 14-15, 26-28), wydaje się szczególnie ciekawa w odniesieniu do dramaturgii Szaloma Asza. W nowoczesnym modelu polsko-żydowskiego paradygmatu dorobek Asza sytuuje się jeszcze wyraźniej w sferze pogranicza, a nawet wzajemnego przenikania wielu płaszczyzn kulturowych, w tym przede wszystkim żydowskiej oraz polskiej². Potwierdzają to najnowsze badania interkulturowe (model polisystemu kultury) Benjamina Harshava, przenoszone na grunt polski w udany sposób przez Prokop-Janiec ${ }^{3}$ (zob. Prokop-Janiec 2014, 9-21). Innym możliwym wariantem staje się próba ukazania dramaturgii Asza w oparciu o podstawowe wyznaczniki młodopolskiego „dramatu wewnętrznego”, dookreślonego przez Jerzego Waligórę jako przejaw procesów upodmiotowienia oraz subiektywizacji dramatu (Waligóra 2004). Zdefiniowane szerzej zjawisko, określone mianem „uwewnętrznienia dramatu” przełomu XIX i XX wieku, prowadziło do odsłaniania autorskich odczuć i pragnień, dla których twórczość dramatyczna stanowiła naturalną płaszczyznę interioryzacji. Proces ten dokonywał się zgodnie $z$ regułami zaproponowanymi przez Stanisława Przybyszewskiego, by „nowy” dramat ignorował prawie zupełnie to „zewnątrz”, skupiając się na tym „wewnątrz” bohaterów. Autor rozprawy O dramacie $i$ scenie, opublikowanej na łamach „Kuriera Teatralnego” w 1902 roku, pisał:

Stary dramat, aż do czasów Ibsena, był właściwie dramatem zewnętrznym. To, co wywoływało konflikt dramatyczny, przychodziło z zewnątrz; rzeczy zewnętrzne wywoływały konflikt, działały na bohatera, pobudzały go do czynu, do zbrodni, a więc rzeczywisty dramat rozgrywał się wokół bohaterów, a nie w nich samych (Przybyszewski 1966, 282).

${ }^{2} \mathrm{~W}$ kontekście podjętych rozważań warto zwrócić uwagę na znacznie szerszy problem badawczy, a mianowicie dorobek literacki twórców pogranicza żydowskiego reprezentujących inne kraje Europy Środkowej, na przykład pisarza i dramaturga czesko-żydowskiego Františka Langera czy jego brata Jiř́ego Mordechaja Langera - hebrajskiego oraz czeskiego pisarza i poety. Dyskurs dotyczący asymilacji polskich Żydów był przedmiotem refleksji Prokop-Janiec (zob. Prokop-Janiec 2014, 9-21).

${ }^{3}$ Odwołując się do koncepcji Benjamina Harshava, Prokop-Janiec wskazuje dwa obszary wzajemnych wpływów: badanie obecności Żydów w kulturze polskiej oraz transferu wzorów polskich w obręb kultury żydowskiej na poziomie wartości przyjmowanych przez obie społeczności (zob. Prokop-Janiec 2014, 12-13). 
Nowy dramat polega na walce indywiduum ze soba samym, tj. z kategoriami psychicznymi, które w stosunku do najgłębiej ukrytych źródeł indywidualnych, stanowiących rdzeń jaźni w obrębie samego indywiduum, tak się mają do niego, jak zewnętrzność do wewnętrzności; pole walki jest tu zmienione, mamy do czynienia z jedną rozłamana, rozbolałą duszą ludzką. Dramat staje się dramatem uczuć i przeczuć, wyrzutów sumienia, szamotania się z sobą samym, dramatem niepokoju, lęku i strachu. (...) Dusza ludzka i to, co się w niej dzieje, stało się punktem wyjścia dla dramaturga (Przybyszewski 1966, 284).

Słowa Przybyszewskiego trafnie określają charakter dramaturgii Szaloma Asza, którego teksty będa - w niniejszych rozważaniach - rozpatrywane jako przykłady „dramatu wewnętrznego" rozumianego w dwojaki sposób. Po pierwsze - jako dramatu wewnętrznego w znaczeniu typu dramaturgii młodopolskiej, z jego konsekwencjami dramaturgicznymi, ze szczególnym uwzględnieniem opisów natury jako pejzażu wewnętrznego podmiotu dramatycznego, po drugie - jako dramatu wewnętrznego dokonującego się w autorze omawianych tekstów, człowieku rozdartym między tym, co tradycyjne i nowoczesne, a także między tym, co wyznaczało pole jego kulturowej tożsamości żydowskiej oraz w mniejszym stopniu polskiej.

Dramat wewnętrzny charakteryzuje uwewnętrzniona perspektywa przestrzenna oraz kreacja podmiotu dramatycznego zdystansowanego wobec bohaterów sztuki, jak i snutej opowieści. Ograniczona do minimum akcja zewnętrzna pozostaje w opozycji do rozbudowanej akcji wewnętrznej, służącej opisowi przeżyć i rozterek bohaterów, które stosunkowo często prezentowane są na tle opisów natury, pełniących funkcję pejzażu wewnętrznego, służącego wyrażaniu emocji dramatis personae bądź samego podmiotu dramatycznego. Reprezentatywne przykłady stosowania techniki dramatu wewnętrznego odnajdujemy niemal we wszystkich sztukach Asza.

W dwuaktowym dramacie Z biegiem fal (Mitn Sztrom) z 1904 roku jego główny bohater Dawid - zięć rabina Reb Zarycha, mąż Racheli i ojciec trzyletniego, a później dziesięcioletniego Szlamka - przeżywa rodzaj wewnętrznego załamania wiary i tożsamości. Odchodzi, bo „mu tu ciasno” i po siedmiu latach powraca do rodzinnego domu żony. Odejście „w świat, do światła, do życia!" (Asz 2013, 33) wiąże się ściśle z procesem wewnętrznego zmagania się z wiarą i stawiania pytań o jej sens, ale także z bolesną koniecznością trwania w domu i wśród ludzi „zmarłych, zimnych, o skostniałym sercu” (Asz 2013, 33). Dawid wyrusza w podróż wczesną wiosna, którą zapowiadają budzące się do życia siły natury. „Wisła budži sie ze zmartego po- 
kerycia, fale plyna z tajemnicza jakas sita, juz to buczq, szumia, zrywaja sie coraz silniejsze... coraz silniejsze..." (Asz 2013, 27)4 - informuja didaskalia poprzedzające właściwą akcję sztuki. Siłę natury dostrzega także Dawid, którego przeżycia wewnętrzne harmonizują z obrazem i odgłosami pękającego lodu oraz szumem rwącej rzeki, budzącej się na nowo do życia: „Z jaką siła pędzi woda! Nadszedł czas jej panowania (gluchy toskot, pekanie lodu i szum wody)" (Asz 2013, 31). Bohater pragnie zerwać krępujące go więzy i wyruszyć ku nowemu, nieznanemu Bogu, gdzieś w świat:

Chcę wam oświecić waszą ciemną niedolę - śmierć wypędzić a życie obudzić. Nie wiem jeszcze w której stronie świata, ale zdaje mi się, że gdzieś daleko, daleko czeka mnie skarb, światło za te dni minione, bez promieni, bez nadziei. Nie chcę syna mojego w niewoli zostawić. (...) Boga chcę dla niego stworzyć (Asz 2013, 34).

Ujarzmiliście mi duszę... Teraz sam jestem, opuszczony... Tamten świat jeszcze daleko, a ten mój, już zburzyłem... Stałem nad przepaścią między dwoma światami (...). Nie mogę już dłużej... Zbudziła się we mnie ta siła, zamknięta dotychczas w niewoli. Naprzód będę patrzył, trupy zostawię, za sobą... (Asz 2013, 37).

Nie zraża go zapowiedź tułaczki, która może zakończyć się niepowodzeniem. Ma tego świadomość rabin Reb Zarych, ostrzegając Dawida przed losem drzewa pozbawionego korzeni:

Dawidzie! Niebo nad głową i ziemię pod stopami straciłeś. Jak cień zbłąkany tułać się będziesz po świecie. Bogów handlarzem się staniesz i jak on - szmaty serca, szmaty duszy w rękach pokazywać będziesz. A wówczas wszystkim bogom będziesz służył, a żaden nie będzie twoim (...). Zatęsknisz... jak ten wiatr, który błądzi po polu i szuka celu... jak to drzewko, które pragnie grudki ziemi, gdzie by mogło zaszczepić swój osierocony korzeń... (Asz 2013, 38).

Idź, szukaj prawdy, gdyż twoją straciłeś! (Asz 2013, 39).

Powrót bohatera po siedmioletniej tułaczce nie zamyka procesu poszukiwania sensu życia i wiary. Skołatane, „sieroce” serce Dawida, przepełnione

${ }^{4}$ We wszystkich cytatach zachowano pisownię oryginalną oraz zapis didaskaliów kursywą przyp. red. 
„wieczną tęsknotą, nie odnajduje spokoju. Mężczyzna wraca do domu, bo zrozumiał, że tęsknił za czymś, co już miał, lecz utracił w pogoni za nieznanym. Porównuje siebie do wykorzenionego, osieroconego drzewa, które będzie mogło rosnąć dalej, pod warunkiem, że ktoś na nowo je „zaszczepi”. Zazdrości swojemu teściowi, rabinowi Zarychowi, pogodzenia z losem Żyda wrośniętego w krajobraz Wisły i Jordanu:

Dwie matki posiadasz, z dwóch piersi mleko ssiesz, Wisły i Jordanu, ty nie wiesz o tym. U ciebie te dwa światy zjednoczyły się, zrosły, stały się treścią twej duszy... (...). Oba te światy, daleki i bliski, stały się twoją jedyną ojczyzną... (Asz 2013, 51).

Po raz kolejny wewnętrzne zmagania bohatera, jego pragnienie wiary, zostaja zderzone z obrazem natury - spokoju człowieka patrzącego na staw w piątkowy wieczór, pośród mgieł rozpościerających się na cały świat, obejmujących pola, lasy, wijącą się nieopodal rzekę. Pogodzenie z ,tą ziemią", z „tą Wisłą” powinno przynosić spokój, ale nie w przypadku Dawida, rozdartego między dwoma światami:

Dwa światy, dwie matki... Ja ani jednego nie posiadam, oba straciłem, jak to młode drzewko, które wiatr unosi w powietrzu, a ono biedne grudki ziemi nie ma, gdzie by mogło swój osierocony korzeń zaszczepić (Asz 2013, 51).

Dawid powraca bez przekonania, że na nowo odnajdzie spokój duszy. Ryzykuje wiele, nawet odrzucenie przez najbliższych, przez ukochanego syna Szlamka. Chce jedynie siedzieć i - jak „duchowy kaleka” - wsłuchiwać się w odgłosy modlitwy rabina:

Po świecie błądziłem, wszystko straciłem, wracam do ciebie... oto tu będę siedzial jak kaleka duchowy i wsłuchiwać się będę w twój głos modlący się. Wiem, że na próżno, wiem! Nie wyganiaj mnie jednak. Patrz!... Świat tam taki ubogi, taki nagi, zimny, cudzy... weź mnie pod swoją opiekę, pozwól mi się grzać przy twoim świetle... (Asz 2013, 52).

Podobne zmagania i wewnętrzne rozdarcie między tym, co stare i nowe staje się udziałem Andrzeja oraz Justyny, dzieci zamożnego żydowskiego kupca Borucha vel Borysa z Warszawy. Bohaterami Czasón Mesjasza (Meszijechs Cajtn), sztuki „współczesnej” w trzech aktach z 1906 roku, są przedstawiciele trzech 
pokoleń żydowskiej rodziny kupieckiej, z których każde realizuje inny model wtapiania się w rzeczywistość polsko-żydowskiego pogranicza. Asymilacja oraz dysymilacja to nie jedyne drogi rozwiązania. Reb Chunen i jego żona Małkełe najstarsze pokolenie tradycyjnej żydowskiej rodziny - postanawiają wyjechać do świętej Ziemi Izraela, by resztę swoich dni spędzić na modlitwie „przy Torze”. Ich synowie reprezentują różne stanowiska wobec procesu asymilacji. Młodszy Josef, ubogi kupiec małomiasteczkowy, zachowuje starą wiarę i żydowskie tradycje. Swego najstarszego syna Bencjona kształci, co prawda, w besmedreszu, ale chłopak reprezentuje postępowe pokolenie młodych Żydów, z ogolonymi głowami, którzy odrzucają „Syjon starców” i nie czekają na przyjście Mesjasza, sami „stając się dla siebie Mesjaszami”. Jego młodsi synowie - Chaim i Mojsze - są prostymi rzemieślnikami, młodymi „Żydami teraźniejszości”, ludźmi podatnymi na aktualne hasła rodzacego się ruchu robotniczo-proletariackiego. Starszy syn Reb Chunena Boruch (Borys) kształci dzieci na uniwersytetach Andrzeja w Szwajcarii, Justynę w Krakowie. Córka Reb Chunena Berta poślubia zamożnego niemieckiego Żyda z Lipska, właściciela dochodowej fabryki wyrobów galanteryjnych, stając się ,zniemczoną Frau”. Uroczyste spotkanie i zarazem pożegnanie nestorów rodu w czasie święta Purim staje się okazją do wyrażenia poglądów wobec procesu asymilacji. Kiedy Justyna, obdarowana przez rodziców dwoma imionami, polskim i żydowskim, po babce Jentełe, zachęca kuzyna do mówienia po polsku, gdyż, znajdując się „,na polskiej ziemi, powinien pan więc mówić po polsku” (Asz 2013, 108), Bencjon odpowiada „asymilatorce” pogardliwie: „Ja mam mówić po polsku? A kto ja jestem: Żyd czy Polak? Jestem Żydem, więc mówię po żydowsku, jak mówili przodkowie nasi w świętym kraju ojczystym” (Asz 2013, 108)5.

Najwięcej wattpliwości związanych z własnym pochodzeniem oraz poczuciem tożsamości rodzi się w umyśle Andrzeja, rozdartego między konsumpcyjnym stosunkiem do bogatego żydowskiego kupiectwa (ojciec i wujostwo), skrajnie religijna postawą Bencjona, rewolucyjnymi poglądami Chaima i Mojszego, a najbardziej asymilacyjną postawą siostry:

Powiedzcie mi dobrzy ludzie, kim jestem? Do kogo należę? Wy, coście mi życie dali, jaki cel daliście mi w życiu? Kogo mam kochać, kogo nienawidzić? Do kogo należeć? (Asz 2013, 115).

\footnotetext{
${ }^{5}$ Stwierdzenie Bencjona, przywołane w kontekście wypowiedzi Justyny, można powiązać pośrednio z sytuacją samego Asza. Badacze jego twórczości zwracają uwagę na fakt, że pisarz tworzył i po hebrajsku, i w jidysz, zaś języka polskiego uczył się i tłumaczył swoje teksty za namową Stanisława Witkiewicza i Stefana Żeromskiego, mając nadzieję na udany debiut na scenie teatru krakowskiego (zob. Kuligowska-Korzeniewska 2011, 29-30).
} 
Chciałem pokochać cudze, chciałem, aby stało się moim. Człowiek musi przecież do kogoś należeć, musi coś mieć. I ja szukałem, u wszystkich bogów szukałem. Chciałem pokochać to cudze, przywiązać się doń, jak do swego (Asz 2013, 119).

„Ziemia, która ciebie wydała, do niej należysz” (Asz 2013, 115) - przekonuje brata Justyna, Żydówka z pochodzenia, Polka z wyboru. Swojemu dziadkowi, który na zawsze wyjeżdża z kraju porośniętego „samotnymi wierzbami i topolami”, radzi, by zabrał garść ziemi do mogiły, ziemi, na której „tyś się rodził, żył i modlił, marzył i płakał”, ziemi, w której „pochowałeś ojca swego, matkę swoją zostawiłeś dzieci swoje, wnuków swoich” (Asz 2013, 138-139). „Weź ją z sobą. Twym ciałem się stała, twoją duszą się stała” (Asz 2013, 139) - nakazuje Reb Chunenowi w momencie pożegnania. Wcześniej jednak przywołuje obraz Żyda-Tułacza, z którego figura porównuje losy swojego dziadka Reb Chunena, wrośniętego w polską ziemię:

Żyłeś tu, dziadku, na tej ziemi, a teraz idziesz umrzeć w jakimś innym kraju! Z obcej krainy przywędrowałeś do nas. Nikt nie wie skąd, nie wie nikt kiedy. Z pierwszym Polakiem znajdują cię już na tej ziemi, o kiju, błądzącego wśród polskich wierzb. I dokądś nie zawędrował, zostawiałeś dziecko. Pod każdym drzewem chowałeś ojca, matkę swoją. Krwią swa, kośćmi swymi usiałeś tę ziemię. (...) A teraz idziesz w inne strony dźwigać swe stare kości. Czy nie chcesz wziąć ze sobą garstki tej ziemi, na której żyłeś, by położyć ją do grobu swego? Patrz (bierze garść ziemi), skrusz ją (rozciera $w$ ręku), być może z jej ziaren wysączy się krew, krople twojej krwi, twojego szpiku, twoich kości, której każda garstka przylgnęła do ciebie! (Asz 2013, 135).

Symbolem wattpliwości rodzących się w sercach oraz umysłach Andrzeja i Justyny staje się kilkukrotnie przywoływana legenda o Esterce, pięknej córce żydowskiego kupca z Opoczna, ukochanej króla Kazimierza Wielkiego (Shmeruk 2000). Justyna pragnie ukoić niepokój błąkającego się wśród ruin ducha Esterki, kobiety pozbawionej przez króla oczu, która teraz nie może stawić się na sądzie ostatecznym. Dziewczyna prowadzi ducha na mogiłę matki. Wydarzenia dokonują się w ,jasna księiycowa noc", gdy ,wszystko wokoto zalane księzycowa poswiata”, a „białe ściany ruin skapane w blasku księ̇yca myraźnie zarysomnja sie na tle ciemnej rieleni drzew” (Asz 2013, 130). Zjednoczenie z „matką-ziemią” ma ukoić i ducha Esterki, i wątpliwości rodzeństwa. Dla Justyny symboliczne połączenie z rodzinną ziemią to zarazem moment dokonującego się wyboru: 
Matko ziemio, co otulasz się w nocne sekrety i zawierasz się w sobie, zabierz mnie, wtul mnie w głębie swej tajemnicy. Matka mi obca, ojciec mi daleki, rodzina odeszła do obcego kraju. Matko ziemio, jam twoje dziecię, z ciebie wyszłam, do ciebie powracam. Przyjmij mnie, przytul do siebie (Asz 2013, 140).

Dla Andrzeja wybór nie jest już tak oczywisty, co potwierdzają kilkukrotnie powtarzane słowa i frazy:

Tu mi obco, tam mi obco... Stoję na granicy kraju i kraju, ludu i ludu, języka i języka. Co chcę, to moje. Wasze głosy mnie nie wołają, mnie nie budzą. Mój ojciec nie dał mi nic, moja matka nie dała mi nic. Nie wiem do kogo należę, nie wiem do kogo należę. Matka zostawiła mnie na bezdrożu. Nie wiem dokąd się zwrócić, na prawo czy lewo? Stoję u szlabanu i nie wiem kim jestem, skąd pochodzę, co twoje, a co moje. Wszystko mi jedno... wszystko jedno... (Asz 2013, 139-140).

Odczytywane w ten sposób przesłanie Czasón Mesjasza prowadzi do wniosku, iż jest to przykład dramatu wyboru, osobistego, niezwykle trudnego wyboru Andrzeja oraz Justyny, tematycznie podobnego do tożsamościowych dylematów Dawida, bohatera $Z$ biegiem fal.

Asymilacja lub jej brak, ale zarazem skala procesu „wtapiania się” w inna, nową rzeczywistość kulturowa, a także konsekwencje przynależności do religii oraz kultury żydowskiej to temat kolejnego dramatu Szaloma Asza, powstałego w 1911 roku. Spadkobiercy (Di Jorszim) podejmuja problem małżeństwa młodej Żydówki Justyny, wywodzącej się z częściowo zasymilowanej, mieszczańskiej rodziny żydowskiej, z ,innym” - gojem i Polakiem, reprezentantem zamożnej arystokracji. Obawy państwa Majzner związane z prawdopodobnym małżeństwem Justyny z hrabia Michałem Dąbrowskim, jak i przyjęciem przez córkę innej wiary, a w konsekwencji wyrzeczeniem się własnej - pozostają w sprzeczności z pragnieniem zapewnienia ukochanemu dziecku szczęścia i miłości. Tym bardziej, że rodzice utracili już wcześniej pierworodnego syna Leona, który, stając się żydowskim „,wolnomyślicielem”, zerwał wszelkie kontakty z rodzina. „Byle tylko, nie za bardzo ich naśladować” (Asz 2013, 210) - powie Pan Majzner, próbując wytłumaczyć sobie i żonie konieczność pogodzenia się z zaistniałą sytuacją. Wizyty hrabiego w domu Justyny wymuszają na rodzinie zmianę codziennych rytuałów. Dzieje się tak również dlatego, że w domu Majznerów mieszka osiemdziesięcioletni „siwiuteńki Żyd” Reb Szmuel, ojciec gospodarza. To właśnie je- 
mu najtrudniej będzie pogodzić się z decyzjami Justyny, która, jak mówi, otrzymała od swoich rodziców wszystko poza wiarą w Boga. Potrzeba żarliwej, autentycznej wiary, obudzona w Justynie już w okresie dzieciństwa przez jej polską (i katolicką zarazem) piastunkę, powiedzie ją do matki Michała - hrabiny Dąbrowskiej. To ona zaprowadzi dziewczynę do kościoła, przedstawi charyzmatycznemu ojcu Antoniuszowi, zaszczepi chęć czynienia dobra poprzez udzielanie się w towarzystwach dobroczynnych. Intencje rodziny Michała, jak się okaże, nie będą do końca prawdziwe. Mężczyzna chce poślubić Justynę i prosić o jej rękę. Stawia jeden warunek - dziewczyna ma zrezygnować z posagu, by nie narazić siebie i przyszłego narzeczonego na ludzką zawiść. W przeciwieństwie do Majznerów rodzina Dąbrowskich, poza tytułami, nie posiada majątku. Plany małżeństwa komplikuje również wrogie nastawienie gojów wobec Żydów. Przypominają o tym słowa Karoliny, siostry Michała, która nieopatrznie formułuje krytyczne opinie na temat Żydów i ich wiary: „O nie, Chrystus kazał nam kochać wszystkich, nawet naszych wrogów” (Asz 2013, 227). W osobie Justyny i jej konwersji Karolina dostrzega możliwość nawrócenia innych Żydów na „prawdziwą wiarę”. Ma jednak wątpliwości związane z kolejnościa przyjmowanych sakramentów. Zawarcie małżeństwa, a następnie przyjęcie chrześcijaństwa może prowadzić do podania w wattpliwość intencji nawrócenia się Justyny. Sformułowane w ten sposób pytanie rodzi kolejne, już w samej Justynie. Młoda kobieta zastanawia się, co to znaczy prawdziwie wierzyć i dlaczego wiara Żydów wywołuje tak wielkie kontrowersje wśród gojów. Także wokół siebie, w swoim rodzinnym domu, dostrzega przejawy szczerej wiary. Dziadek Reb Szmuel nie rozstaje się ze świętymi księgami Tory, modląc się całymi dniami słowami psalmów:

Przecież nie może być nic złego w żydowskich księgach, które zostały uznane za święte również przez Kościól. Nie wiem, czego od nich chcecie i dlaczego obrzucacie je podejrzeniami. Powiedz, jaka klątwa na nich spoczywa, jakimi grzechami są obciążone. Powiedz, co jest w tych księgach? Kimże są Żydzi, że należy ich traktować podejrzliwie i z niechęcią? (Asz 2013, 231).

Początkowo Justyna jest gotowa wyrzec się wszystkiego, by być szczęśliwą u boku Michała. Jednak uporczywe próby zdeprecjonowania przez bliskich hrabiego wiary jej przodków wywołują przeciwny skutek. Wyrażane przez matkę i siostrę Michała powątpiewanie w intencje konwersji Justyny i łączenie tego faktu z chęcią skonsolidowania majątków Majznerów oraz hrabio- 
stwa Dąbrowskich prowadzą kobietę do zwątpienia w sens miłości. Bycie „uczciwym człowiekiem” i „uczciwym Żydem w cywilizowanym świecie” okazuje się niewystarczające, by córka bogatego żydowskiego kupca mogła bez przeszkód poślubić hrabiego. Podejrzliwość i pogarda gojów wobec Żydów wydają się nie mieć końca. Potwierdzają to również słowa Michała, który próbuje wytłumaczyć Justynie istniejące między nimi różnice kulturowe:

Cywilizowani. Ubierają się według ostatniej mody paryskiej, mówią w światowych językach, a jednocześnie są tacy bezradni. Każdy może obrażać ich żony, hańbić ich córki, jak zdarzyło się całkiem niedawno, a one nie mają nikogo, kto ująłby się za nimi... Obnoszą się swoim bogactwem, jakby pieniądz był ich domem. Tak łatwo przejmują obyczaje każdego kraju... (Asz 2013, 237-238).

Michał nie zdaje sobie sprawy z tego, jak bardzo te słowa zabola, ale i oburza Justynę, która na nowo zacznie zastanawiać się nad swoją tożsamością: „,, ja pusta żydowska córka, przystrojona cywilizacją, ale naga i uboga jak najbiedniejsze cygańskie dziecko!...” (Asz 2013, 238). Młoda kobieta odnajdzie pocieszenie $\mathrm{w}$ tradycji przekazywanej $\mathrm{z}$ pokolenia na pokolenie przez ukochanego dziadka, który pomimo swojego wieku dobrze rozumie różnice między współczesną tolerancją dla wiary i obyczaju ,innych”, a trwaniem w wierze oraz tradycji przodków:

Mam milczeć, gdy widzę, że moje światło wypala się, że moje dziecko zrywa ze wszystkim, co ja i moi przodkowie ratowaliśmy za cenę własnej krwi? Mam nic nie mówić, widząc pustkę, do której jak do czarnej otchłani wpadam wraz ze wszystkim, co po mnie zostanie. To się nazywa tolerancja? (Asz 2013, 242).

Dramat wiary Justyny, oznaczający pustkę życia „pozbawionego korzeni”, przeradza się w próbę poszukiwania nowych wartości. Justyna odnajduje w sobie siłę, by na nowo przewartościować swoje życie, życie „,̇ydowskiego dziecka", naznaczone tradycja i przywiązaniem do rodziny. Podobnie jak dziadek pragnie odczuwać ,żydowski ból” istnienia, związany silnie z poczuciem przynależności do innej wiary i kultury, który - z jednej strony oznacza odrzucenie przez większość społeczeństwa bądź pozostawanie na uboczu życia, z drugiej - wiąże się z siłą wielu pokoleń czerpaną z żydowskiej tradycji. Justyna odnajduje więc pocieszenie w postawie starszego brata Leona, który już wcześniej podążył za wewnętrznym głosem „żydowskiego 
światełka”. Odkrywając swoją własną drogę żydowskiej wiary, odnajduje zarazem szczęście i pogodzenie z losem współczesnego Żyda. Tego samego pragnie dla siebie Justyna. Odrzucając powierzchowność dostatniego życia córki żydowskiego kupca oraz miłość do Michała, pozbawioną ,żydowskiego wiana”, która dlatego właśnie nie może znaleźć spełnienia, Justyna rozumie, że tak jak Leon musi odnaleźć swoją własną drogę i „piękno swojego narodu".

W kontekście podjętych rozważań warto zwrócić uwagę na najbardziej plastyczne obrazowanie zastosowane przez Asza w Grz̧eszniku (Der Zwindiger), zatytułowanym pierwotnie Ziemia nie chce go prayjać, jednoaktowym obrazie scenicznym z 1904 roku, który nie bez powodu porównywany jest do Wnętrąa Maeterlincka. Skala ,uwewnętrznienia” sztuki opiera się na prostym zamyśle dramaturgicznym. Asz prezentuje opis uroczystości pogrzebowych nieznanego Żyda, którego „nie chce przyjać ziemia” małomiasteczkowego żydowskiego cmentarzyska, otoczonego „niskim, starym, drewnianym plotem”, gdzie pośród „gesto obrośnietych drzewek” kryją się „macewy w polowie porośniete trawa” i „pasq sie kozy” (Asz 2013, 87), jak informuja szczegółowo didaskalia. Działania sceniczne grabarzy oraz przedstawiciela Bractwa Pogrzebowego Gabaja rozgrywają się w świetle ,płonqcego, zachodzqcego stońca” i nie przynoszą skutku. Przypatruje się im "miejscony pomyleniec otulony podarta kapota”. Mogiła nie jest jeszcze gotowa, choć „mrok zapada - zimny wiatr wieje kolyszqc drzewa”, a „na ciemnej drodze z drugiej strony plotu widać nadchodzacy kondukel" (Asz 2013, 88). Początkowo w miejscu pochówku grabarze wykopuja ludzkie szczątki, a następnie dokopują się do źródełka. Gdy Gabaj zmienia lokalizację grobu na miejsce przy urnie cnotliwego Reb Judla, jego kamień macewy, ułożony u wezgłowia, nie pozwala na kontynuowanie ceremonii. Dopiero rytuał wrzucenia w ogień siedmiu cegieł, zaproponowany przez rabina oraz sędziów sądu rabinackiego, sprawia, że pogrzeb może się odbyć. Statyczna akcja zewnętrzna dramatu pozostaje w opozycji do rozbudowanej akcji wewnętrznej, służącej opisowi przeżyć bohaterów sztuki - nieznanego Żyda, ale przede wszystkim jego tajemniczej partnerki - Kobiety w Czarnym Welonie. Ta żona lub kochanka, gojka lub Żydówka, będzie odmawiała po zmarłym kadysz, choć wcześniej „nigdy w bożnicy nie była” i „do kościoła też nie poszła” (Asz 2013, 89), jak ironicznie, a po części lekceważąco podsumuja jej zachowanie bezimienni współuczestnicy pochówku. Uwzględniając omawiane wcześniej dramaty Asza, pozornie żaden z bohaterów Gržesznika nie przeżywa tak intensywnego zmagania się ze swoim losem czy też z przeznaczeniem. Biorąc jednak pod uwagę siłę wyrazu milczącego uczest- 
nictwa w pogrzebowej ceremonii Kobiety w Czarnym Welonie oraz obrazujące je przemiany w świecie natury (płonące słońce, ciemna droga, zniszczone cmentarzysko, macewy porośnięte trawa, zimny wiatr, rozkołysane drzewa), otrzymujemy kolejny emotywnie nacechowany obraz dramatyczny rodem z Wnetrza.

Milcząca obecność „kobiety w czerni” nakreślona zostaje jedynie poprzez informacje zawarte $\mathrm{w}$ didaskaliach. Początkowo bohaterka stoi razem $\mathrm{z}$ innymi, w milczeniu, u wezgłowia łóżka zmarłego mężczyzny, kryjąc twarz w dłoniach. Następnie, w chwili zamieszania, zostaje z nim sama, klęka przy zwłokach, kryjąc twarz w fałdach okrycia, którym przykryty jest trup. Gdy na cmentarz przybywa rabin $z$ dajanami, kobieta nadal klęczy przy grobie i głośno płacze. W czasie ceremonii ognia i siedmiu cegieł, kiedy wiadomo już, że jedna z cegieł pozostaje nienaruszona, rabin nakazuje posługaczowi przekazanie umarłemu informacji, że ,nie jest mężem tej kobiety ani ona jego żona”" (Asz 2013, 97). Dopiero wówczas ceremoniał pogrzebu zostaje zakończony. Kobieta nadal klęczy, a w jej obecności grabarze „źdejmuja trupa z. noszy i okrytego czarnq szata kłada do grobu" (Asz 2013, 97), rozbijaja gliniany garnek i skorupkami zasłaniaja oczy oraz usta zmarłego, po czym zasypuja grób. Kobieta w Czarnym Welonie odzywa się tylko raz, na samym początku uroczystości, gdy przemawia po polsku: „Pozwólcie mi raz jeszcze spojrzeć na niego!...” (Asz 2013, 89), co napotyka na zdecydowany sprzeciw Gabaja - „Nie wolno! (z daleka w jidysz)”. Milczącą obecność kobiety wzmacnia kolorystyka kolejnych scen/obrazów. Pogrzeb zaczyna się, gdy:

Czarne wrota otwieraja się z hałasem. Czterech tragarzy wnosi na barkach nosze, stawiaja je pod słupami, zdejmują wierzchnią deskę. Spod czarnego okrycia sterczą stopy i głowa. Kobieta w czerni stoi w milczeniu u wezgłowia, kryjąc twarz w dłoniach. Tragarze chcą unieść nosze. Słychać z daleka głos. Przez kilka minut cisza (Asz 2013, 89).

Sztukę zamyka kolejny obraz precyzyjnie zarysowany w didaskaliach:

Na scenie robi się ciemno. W głębi na tle ciemnej nocy dogasają ostatnie iskierki ogniska, a przy ich słabym świetle widać, jak podnosi się kobieta w czerni, zbliża się cichym krokiem do grobu i rzuca na niego swój czarny welon. W oddali na drodze widać jeszcze światełka oddalających się latarni. Kurtyna z wolna opada (Asz 2013, 97).

Pomimo szczątkowej formy zewnętrznej akcji dramatycznej oraz znaczącej subiektywizacji opisanego świata przeżyć Kobiety w Czarnym Welonie, 
proces uwewnętrznienia przestrzeni rzeczywistej Grzesżnika powoduje, iż dramat ten można uznać za reprezentatywny przykład młodopolskiego dramatu wewnętrznego.

$\mathrm{Na}$ koniec rozważań warto powrócić do kwestii dramatu wewnętrznego przeżywanego przez Szaloma Asza, co wydaje się równie istotne w kontekście jego twórczości dramatycznej. Emotywne nacechowanie sztuk Asza, w których większość głównych bohaterów przeżywa rodzaj dramatu wewnętrznego - dramatu rozterek i zmagania się z sobą samym, swoją wiarą oraz przekonaniami, tożsamością religijną bądź kulturową prowadzi do wniosku, iż dramaty te przynależą do typu dramaturgii przestrzeni wewnętrznej. Podobnego określenia używa Eugenia Prokop-Janiec, posługując się terminem „opowieści przestrzenne”, w odniesieniu do wybranych przykładów prozy Asza, w których, jak przekonuje badaczka, pisarz korzysta z precyzyjnych sformułowań topograficznych, kreślonych z punktu widzenia postaci przemierzającej daną przestrzeń (zewnętrzną, ale i wewnętrzna) lub z konstrukcji narratora-samotnego przybysza, zdystansowanego wobec epickiego świata przedstawionego (zob. Prokop-Janiec 2011, 58-59). Podobna technika pojawia się w jego dramaturgii przestrzeni wewnętrznej, dodatkowo eksponującej opisy natury, korespondujące $\mathrm{z}$ przeżyciami wewnętrznymi bohaterów. Zwłaszcza sztuki Z biegiem fal, Grzesżnik oraz Czasy Mesjasza precyzyjnie dookreślają relacje przestrzenne oraz sposób ulokowania postaci względem określonych wyznaczników przestrzennych. Plastyczne obrazowanie przestrzenne wzmacniaja niezwykle precyzyjne didaskalia ${ }^{6}$, jak w przypadku przywołanego już wcześniej opisu zachowania Kobiety w Czarnym Welonie (Grzesz̧nik) czy działań Dawida, bohatera $Z$ biegiem fal, który chce wyjawić Racheli prawdę o planowanym odejściu:

Przystępuje do drzwi na prawo. Chce wejść, przystaje chwilkę, przysłuchuje się, wpatrując się w dziurkę od klucza. Po chwili oddala się, kręci

${ }^{6}$ Didaskalia pełnią podobną funkcję we wszystkich dramatach Asza. Jako przykład można przywołać charakterystyczny opis zachowań kobiet - matki i dwóch córek, bohaterek sztuki Zima (Un Winter), w której część działań scenicznych oraz znamiennych scen milczących również tych z dialogiem wewnętrznym - rozgrywa się w tekście pobocznym: „Debora stoi pośrodku pokoju z zatożonymi rekoma, widać, że nie wie, co ma zrobić. Chce podejś́ do córki, ale waha sie - wreszcie siada gdzieśs w kaciku i mówi do siebie, »Ja, nieszczęsna matka... Mój Boże, co mam począć?... «. Patrzy na Rome, która nie odpowiada, siedzqc zamyślona. Przez dtu̇̀szq chwile na scenie panuje cisza. Z drugiego pokoju dobiegaja nagle odgtosy froterowania podtogi. Wesoly glos Julki komenderuje: »Proszę postawić ten oleander na podłodze przy oknie. Firanka przesłania lustro!«. Roma spoglada na matke. Matka wyglada przez okno" (Asz 2013, 202). 
się nerwowo po pokoju, walcząc ze soba. Nareszcie zbliża się do starej szafy, wyjmuje spoza książek parę sztuk bielizny i kilka małych zeszytów, i owija to wszystko w chustkę (Asz 2013, 31).

Słowa, emocje oraz sposób przeżywania rzeczywistości przez Dawida w kontekście kategorii dramatu wewnętrznego, ale również funkcji didaskaliów w dramacie młodopolskim (zob. Woźniakiewicz-Dziadosz 1970) można, jak się wydaje, zestawiać z rozterkami samego Asza, który, zapewne, podpisałby się pod cytowanymi już wcześniej słowami:

Dwa światy, dwie matki... Ja ani jednego nie posiadam, oba straciłem, jak to młode drzewko, które wiatr unosi w powietrzu, a ono biedne grudki ziemi nie ma, gdzie by mogło swój osierocony korzeń zaszczepić (Asz 2013, 51).

Podobnie wybrzmiewa deklaracja Justyny, bohaterki Czasów Mesjasza, dla której Polska staje się umiłowaną ojczyzną:

$\mathrm{Na}$ ziemi polskiej się urodziłam, na polskich łąkach wzrastałam. Słońce, co zalewa brzaskiem polskie pola, ujrzały me oczy, gdym je po raz pierwszy otworzyła. Mój dom - to ziemia, która wydała mnie z łona swego, mlekiem swym wykarmiła. Żadnego innego domu, żadnej innej ojczyzny nie znam i nie mam (Asz 2013, 113).

Ten rodzaj wewnętrznego rozdarcia czy może raczej zawieszenia między dwoma światami zawiera - z jednej strony - kluczowe dla Asza stwierdzenie: „Piszę o życiu Żydów, bo znam to życie” (Jankowski 1959, 168), z drugiej - sformułowanie zawarte w jego autobiografii zatytułowanej Spojrzenie wstecz z 1930 roku. Pisarz przekonuje, że uczył się od Stanisława Witkiewicza i Stefana Żeromskiego nie tylko swojego rzemiosła (,zawodu”), ale także służenia bez reszty „mojemu narodowi”, Polsce (Asz 1958, 18). Symbolem owego rozdarcia staje się przede wszystkim Justyna ze Spadkobierców, postać zawieszona między tym, co polskie i żydowskie. Bohaterka dramatu porównana zostaje przez Bencjona do „oskubanej wierzby” - drzewa ważnego w symbolice judaizmu, oznaczającego drzewo lamentacji rosnące nad rzekami Babilonu, pod którym Izraelczycy opłakiwali swój niewolniczy los, ale zarazem drzewo-symbol Żyda, który nie studiuje Tory i nie wypełnia bożych przykazań, gdyż wierzba to roślina, która nie rodzi owoców i nie pach- 
nie $^{7}$. Dlatego, jak się wydaje, sztuki Szaloma Asza, wpisujące się w model dramatów tożsamościowych, opartych na konieczności dokonania wyboru między tym, co było, a tym, co będzie, między przeszłością i tradycją, a teraźniejszością i związaną z nią nowoczesnością ${ }^{8}$, to zarazem przykłady młodopolskiego dramatu wewnętrznego, tak silnie nacechowanego emotywnie.

\section{Literatura}

Asz Sz., 1958, Spojrzenie wstecz, przeł. Koprowski J., „Twórczość”, nr 5.

Asz Sz., 2013, Dramaty. Wybór, Kuligowska-Korzeniewska A., Adamczyk-Garbowska M., red., przeł. Gottlieb H., Adamczyk-Garbowska M., Huzarska W., Ruta M. i in., Kutno.

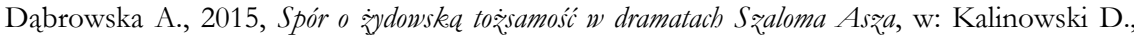
red., Szalom Asz dialogiczny. Wstępne rozpoznania, Kutno.

Jankowski E., 1959, O ,polskim” epizodzie Szaloma Asza, „Przegląd Humanistyczny”, nr 3.

Kalinowski D., 2013, Szalom Asz, wobec konwencii dramatu XIX i XX wieku, w: Kalinowski D., red., Swiat dramatón Szaloma Asza, Kutno.

Kuligowska-Korzeniewska A., 2011, Polskojesyczny debiut teatralmy Szaloma Asza, w: Kalinowski D., red., Szalom As₹: Polskie i sydowskie konteksty twórczości, Kutno.

Polski stownik judaistyczny, http://www.jhi.pl/psj/arawa [dostęp: 10.02.2018].

Prokop-Janiec E., 2010, Powieść etnografična a kultury mniejszości, w: Bukowiec P., Siwor D., red., Etniczność, to ̇̌samosíc, literatura. Zbiór studión, Kraków.

Prokop-Janiec E., 2011, Szalom Asz i Krakón, w: Kalinowski D., red., Szzalom As\% Polskie $i$; ydowskie konteksty twórçości, Kutno.

Prokop-Janiec E., 2012, Etnopoetyka, w: Walas T., Nycz R., red., Kulturowa teoria literatury 2. Poetyki, problematyki, interpretacje, Kraków.

Prokop-Janiec E., 2014, Kulturowe i literackie kontakty polsko-ìydowskie, w: Prokop-Janiec E., red., Polacy - Żydri. Kontakty kulturowe i literackie, Kraków.

Przybyszewski S., 1966, O dramacie i scenie, w: Przybyszewski S., Wybór pism, oprac. Taborski R., Wrocław-Warszawa-Kraków.

Shmeruk Ch., 2000, Legenda o Esterce w literaturze jidysz i polskiej, przeł. Adamczyk-Garbowska M., Warszawa.

Sitarz M., 2010, Literatura jako medium pamiecci. Świat powieści Szolema Asza, Kraków.

${ }^{7}$ Zob. [hasło wierz̧ba, hebr. arawa], Polski stownik judaistyczny, http://www.jhi.pl/psj/arawa [dostęp: 10.02.2018].

8 Podobnie można rozumieć tradycję Festiwalu Szaloma Asza, który odbywa się w Kutnie co dwa lata (w 2019 roku planowana jest XI edycja festiwalu), a któremu towarzyszy Ogólnopolski Konkurs Literacki im. Szaloma Asza. Organizatorem festiwalu oraz konkursu jest Miejska i Powiatowa Biblioteka Publiczna im. Stefana Żeromskiego, której działania mają na celu przywracanie pamięci o polsko-żydowskiej przeszłości Kutna, w tym także o Szalomie Aszu, twórcy urodzonym w Kutnie w 1880 roku w ortodoksyjnej rodzinie żydowskiej. 
Sitarz M., 2013, Dramaty Szolema Asza czytane dzisiaj, w: Kalinowski D., red., Świat dramatów Szaloma Asza, Kutno.

Stykowa M.B., 1983, Legendarna inscenizacja Młodej Polski (Wnętrze M. Maeterlincka w reżyserii T. Pawlikowskiego), w: Sławińska I., Stykowa M.B., red., W'śód mitów teatralnych Młodej Polski, Kraków.

Waligóra J., 2004, Mtodopolski „dramat wewnętrzny”, Kraków.

Woźniakiewicz-Dziadosz M., 1970, Funkecje didaskaliów w dramacie mtodopolskim, „Pamiętnik Literacki”, z. 3. 